\title{
ОСОБЕННОСТИ ВНУТРЕННЕЙ ПОЗИЦИИ РОДИТЕЛЯ У ДЕТЕЙ МЛАДШЕГО ШКОЛЬНОГО ВОЗРАСТА
}

\author{
Галина Григорьевна Филиппова \\ доктор психологических наук, профессор \\ Московский гуманитарный университет \\ 2. Москва, Россия \\ E-mail: filippova_galina@mail.ru

\section{Светлана Александровна Абдуллина \\ педагог-психолог ГБОУ СОШ № 1989 2. Москва, Россия E-mail: abdullina.sa@mail.ru}

Статья посвящена изучению формирования основ внутренней позиции родителя у детей младшего школьного возраста. Делается предположение, что первичная внутренняя позичия родителя появляется задолго до появления собственных детей, а ее компоненты формируются в онтогенезе в соответствии с этапами становления родительской сферы личности. Выделяются компоненты внутренней позиции родителя и описывается их содержание применительно к младшему школьному возрасту. Определяются критерии сформированности компонентов первичной внутренней позиции родителя у младших школьников, изучаются факторы, влияющие на ее становление, а также описываются различия формирования компонентов у мальчиков и девочек.

В исследовании приняли участие 85 детей в возрасте от 8 до 9 лет (39 мальчиков и 46 девочек). В качестве методического инструментария был применен эксперимент, в рамках которого создавались условия для режиссерской игры, контент-анализ детских высказываний, а также проективные и анкетные методы сбора данных. Оценивались характеристики рисунков, высказывания и действия детей в воображаемой роли родителя.

В результате исследования были выявлены наиболее яркие критерии сформированности компонентов внутренней позиции родителя, а именно: желание иметь более двух детей в будущем, наличие положительных высказываний о ребенке, использование поддержки в эмочионально значимых ситуациях, использование ласкового обращения к ребенку. Полученные 
результаты также позволили выявить недостаточный уровень сформированности мотивационного (представление своей будущей семьи без детей) и когнитивного компонентов внутренней позиции родителя (формальный характер высказываний о ребенке) узначительной части младших школьников.

Ключевые слова: родительство, онтогенез родительства, этап нянченья, ВПР (внутренняя позиция родителя), компоненты ВПР, представления о ребенке, отношение к детям, ченность ребенка, воспитательные воздействия, младшие школьники.

Для цитирования: Филиппова Г. Г., Абдуллина С. А. Особенности внутренней позиции родителя у детей младшего школьного возраста // Российский психологический журнал. - 2016. - Т. 13. - № 3. - С. 123-139.

\title{
FEATURES OF THE INTERNAL POSITION OF A PARENT IN PRIMARY SCHOOL-AGE CHILDREN
}

\author{
Galina Grigor'evna Filippova \\ Doctor of Psychology, Professor \\ Moscow University for the Humanities \\ Moscow, Russia \\ E-mail: filippova_galina@mail.ru \\ Svetlana Aleksandrovna Abdullina \\ Pedagogue-Psychologist \\ Secondary school № 1989 \\ Moscow, Russia \\ E-mail: abdullina.sa@mail.ru
}

The paper examines the formation of the bases of the internal position of a parent in primary school-age children. The person's internal position of a parent appears long before the birth of his/her own children; its components are formed in ontogenesis in accordance with the stages of the development of the parental sphere of personality. This study attempts the following: to disringuish components of the internal position of a parent; to explain the content of these components concerning primary school age; to define the criteria of the formation of the components of the primary internal position of a parent in primary school children; to examine the factors influencing the development of the primary internal position of a parent in primary school children; to describe the differences in the formation of components of the primary internal position of a parent in boys and girls. 
The study involved 85 children aged 8 to 9 years (39 boys and 46 girls). An experiment, creating the conditions for video games, content analysis of children's statements, and projective and questionnaire methods were methodological tools of the study. The authors evaluated characteristics of drawings, statements and actions of children in the imaginary role of a parent.

Most prominent criteria of the formation of the components of the internal position of a parent include the following: (a) the desire to have more than two children in the future; positive statements about the child, (b) use of support in emotionally significant situations, (c) use of endearment to a child. The obtained results also revealed a low level of the development of motivation (representation of the future family without children) and cognitive components of the internal position of a parent (formal statements about the child) in a significant number of junior schoolchildren.

Keywords: parenthood, ontogenesis of parenthood, period nursing, IPP (internal position of a parent), components of IPP, representation of a child, relation to children, value of a child, educational influences, junior schoolchildren.

For citation: Filippova G. G., Abdullina S. A. Features of the Internal Position of a Parent in Primary School-Age Children. Russian Psychological Journal, 2016, V. 13 , no. 3, pp. 123-139.

\section{Введение}

Изучение формирования личностных основ родительства в онтогенезе является одним из малоизученных вопросов в современной науке. Исследователи подчеркивают определяющую роль личностной истории в становлении родительства $[2,8,12,20]$, однако исследований особенностей формирования родительской сферы у детей практически не существует. Родительство как психологический феномен рассматривается с двух позиций - как особое качество самосознания человека, при котором он осознает себя родителем, а также как деятельность, направленная на рождение, выращивание и воспитание ребенка $[2,3,18]$. В современной литературе, посвященной изучению готовности подрастающего поколения к родительству, подчеркивается идея о том, что традиционные пути к передаче модели родительства и родительского поведения уходят в прошлое. Семья больше не является институтом, который передает эти модели посредством приобщения детей к уходу за младшими членами «широкой» семьи $[12,14$, $15,19]$. Это ведет к нарушениям в родительской сфере, а именно к дефицитарности родительской компетентности, отсутствию адекватной мотивации рождения детей, а также к отсутствию эффективных моделей воспитания детей [15]. Молодые родители вынуждены сталкиваться с необходимостью 
самостоятельно выстраивать стратегии воспитания, обращаясь при этом к различным и не всегда согласующимся между собой мнениям специалистов. В данных условиях одним из важнейших компонентов психологической готовности к осуществлению родительской деятельности будет являться выстроенная осознанная родительская позиция, которая формируется, начиная с самого раннего возраста.

Наше исследование посвящено изучению особенностей формирования Внутренней позиции родителя (ВПР), которое было впервые представлено Е. И. Захаровой и рассмотрено в ситуации присвоения социальной позиции родителя в связи с рождением ребенка. Внутренняя позиция родителя определяется как личностное образование, отражающее индивидуальное отношение к социальной позиции родителя, которую человек занимает или стремится занять в будущем, а также влияющее на ее принятие и освоение $[1,2]$. О. А. Карабанова рассматривает формирование внутренней позиции матери и отца отдельно, считая, что внутренняя позиция матери - это новообразование периода беременности, а формирование родительской позиции отца начинается со второй половины беременности жены и распространяется на первый год жизни ребенка [4]. На наш взгляд, компоненты ВПР начинают формироваться задолго до появления собственных детей $[5,8,20]$. По аналогии с тем, как внутренняя позиция школьника формируется до фактического поступления ребенка в школу и является итогом благополучного развития дошкольника $[1,7,9]$, так и компоненты ВПР формируются до факта наступления беременности. К моменту вступления в актуальное родительство у человека уже существует определенная ВПР, которая отражает его предварительную готовность к родительской деятельности и будет преобразовываться в процессе реального освоения родительства. Эту предварительную позицию мы обозначили как первичную внутреннюю позицию родителя.

Теоретической основой нашего исследования является онтогенетическая концепция материнства Г. Г. Филипповой, которая рассматривает онтогенез родительской сферы и выделяет 6 этапов, охватывающих все периоды становления родительства, начиная с раннего младенчества [18]: 1) этап взаимодействия с собственной матерью в раннем онтогенезе; 2) игровой этап и взаимодействие со сверстниками (3-5 лет); 3) этап нянченья (5 / 6-11 лет); 4) этап дифференциации ценностно-смысловых основ моделей партнерских и родительских отношений (11-15 лет) и этап мотивационной готовности к родительству (15-18 лет); 5) этап взаимодействия с собственным ребенком до сохранения у него основных компонентов гештальта младенчества; 6) взаимодействие с ребенком как с развивающейся личностью. Данная периодизация относится как к онтогенезу материнства, так и отцовства, т. к. по мнению ряда исследователей, принципиальных различий в родительском 
уходе за ребенком между мужчиной и женщиной нет, и гораздо важнее учитывать индивидуальные различия, а не межгрупповые [6].

В нашем исследовании была поставлена задача изучения одного из ранних этапов развития родительской сферы - этапа нянченья, который включает возраст от 5 / 6 до 11 лет. Этот этап является очень важным для формирования родительской сферы, а также самым благоприятным для первого знакомства и взаимодействия с младенцами [18].

На предыдущем этапе развития родительской сферы, в дошкольном возрасте, дети осваивают навыки ухода и свои чувства к младенцам в процессе сюжетно-ролевой игры с куклой. Становясь старше, дети начинают проявлять интерес уже к живым младенцам, стремясь приобщиться к деятельности взрослых. Младшие школьники обладают достаточной для этого физической силой и ловкостью. На этапе нянченья формируется потребность в заботе о младенце, потребность в переживаниях, получаемых в процессе взаимодействия с ним, которая подкрепляется проявлением эмоций младенцем при общении [18]. При взаимодействии с младенцами у младших школьников формируются основы родительской компетентности: способность понимать состояние ребенка и его потребности, отвечать на его сигналы, навыки взаимодействия с ребенком.

Особенностью этапа нянченья является формирование первичного типа интерференции ценности родительства и ценностей из других сфер, таких как профессиональная и личная успешность [18]. Дети на примере своих родителей и социального окружения усваивают ценностные приоритеты. Также на этом этапе важно разделение ценности «себя как ребенка» и «ребенка для себя (других детей для взрослых)» с последующей интеграцией этих ценностей по мере взросления [18]. Эти процессы возможны исключительно при наличии у младших школьников возможности получить опыт взаимодействия с младенцами и наблюдения за таковым других взрослых.

По мнению Г. Г. Филипповой, если первый опыт взаимодействия с младенцами приходится на ранний возраст до начала этапа нянченья, то это может вызвать ревность, т. к. дети чувствуют уменьшение внимания к себе со стороны взрослых, а ценность «себя как ребенка» еще недостаточно дифференцирована от ценности «ребенка для себя». Если первое взаимодействие с младенцем происходит на этапе нянченья, но его недостаточно или он был кратковременным или неудачным, то возможно возникновение страха перед младенцами в будущем. Если опыта в период нянченья не было совсем, а первое знакомство с младенцами произошло в подростковый период, то это может вызвать неприязнь и раздражение [18].

Таким образом, благополучное завершение этапа нянченья в плане развития родительской сферы должно характеризоваться наличием достаточного 
количества опыта во взаимодействии с младенцами. Этот опыт должен быть подкреплен поощрительными действиями со стороны ближайших взрослых. Социальная оценка деятельности детей и ее результатов играет огромное значение в формировании чувства умелости и уверенности в своих силах, в том числе в такой деятельности, как взаимодействие с младенцем.

Основываясь на теоретическом анализе научной литературы [10], мы выделили четыре компонента внутренней позиции родителя: мотивационный, когнитивный, эмоциональный и поведенческий. Мы предположили, что особенности внутренней позиции родителя в младшем школьном возрасте будут отражаться в содержании каждого из компонентов ВПР.

Целью нашего эмпирического исследования стало изучение содержания компонентов ВПР в младшем школьном возрасте и выявление факторов, влияющих на ее становление. Также мы планировали выявить различия в воспитательных стратегиях, представлениях о ребенке и будущей семье у мальчиков и девочек и проанализировать влияние опыта общения с младенцами (наличие младших сиблингов) на формирование ВПР.

Выборка состояла из 85 детей, обучающихся в ГБОУ СОШ 1989 г. Москвы, из них 39 мальчиков и 46 девочек в возрасте 8-9 лет. У 38 детей есть младшие сиблинги, у 25 детей есть только старшие сиблинги, 26 детей-единственные в своей семье.

\section{Методы исследования}

Для изучения содержания компонентов ВПР были использованы следующие методы исследования: контент-анализ рассказа «Что такое ребенок» [13], эксперимент, в рамках которого создавались условия для режиссерской игры «День ребенка» $[16,17]$ (авторская методика Г. Г. Филипповой, С. А. Абдуллиной), рисуночные методики «Моя семья», «Моя семья в будущем» Т. В. Пальцевой [11], анкетные методы сбора данных.

Для анализа были выделены показатели, по которым оценивалось содержание компонентов ВПР у младших школьников. Оценивались характеристики рисунков, высказывания и действия детей. Содержание компонентов представлено в таблице 1.

\section{Результаты и их обсуждение}

Мотивационный компонент внутренней позиции родителя оценивался по рисунку «Моя семья в будущем», а также по игре «День ребенка». На рисунке «Моя семья в будущем» рисуют своих будущих детей лишь $57 \%$ испытуемых, у остальных 43 \% дети на рисунке отсутствуют. В будущей семье без детей мальчики чаще изображают себя с друзьями или в одиночестве, а также с автомобилем или рядом с офисом. А девочки чаще рисуют себя 
с домашними питомцами. Среди девочек $26 \%$ не изображают своих будущих детей на рисунке будущей семьи, среди мальчиков-59\%. Данные результаты могут косвенно являться проявлением тенденции нарушения семейной структуры в современном обществе [21, 22]. Дети представляют свою будущую семью не только как пару с детьми, но и как пару без детей, также как семью из одного человека, как человека с друзьями или как свою настоящую семью. Эти данные представлены на рисунке 1.

Таблица 1.

\section{Содержание компонентов внутренней позиции родителя у детей} младшего школьного возраста и критерии их оценки по методикам

\begin{tabular}{|c|c|c|}
\hline Компоненты & Содержание компонента & $\begin{array}{l}\text { Название методики: ана- } \\
\text { лизируемые показатели }\end{array}$ \\
\hline Мотивационный & $\begin{array}{l}\text { Желание взаимодействовать } \\
\text { с ребенком } \\
\text { Желание заботиться о нем } \\
\text { Желание стать родителем }\end{array}$ & $\begin{array}{l}\text { «Рисунок семьи», «Рисунок } \\
\text { будущей семьи»: } \\
\text { Представление своей бу- } \\
\text { дущей семьи с детьми. } \\
\text { Ценность ребенка. } \\
\text { Игра «День ребенка»: } \\
\text { Ценность ребенка }\end{array}$ \\
\hline Эмоциональный & $\begin{array}{l}\text { Эмоциональное отношение } \\
\text { к ребенку, к себе как к будущему } \\
\text { родителю } \\
\text { Родительские чувства и ожидания } \\
\text { относительно появления ребенка } \\
\text { в будущем }\end{array}$ & $\begin{array}{l}\text { «Ребенок-это...»: } \\
\text { Эмоциональный знак выска- } \\
\text { зываний о ребенке. } \\
\text { «Рисунок семьи», «Рисунок } \\
\text { будущей семьи»: } \\
\text { Психологический комфорт } \\
\text { в позиции родителя. } \\
\text { Игра «День ребенка»: } \\
\text { Принимающая позиция } \\
\text { по отношению к ребенку }\end{array}$ \\
\hline Когнитивный & $\begin{array}{l}\text { Представления о ребенке, об осо- } \\
\text { бенностях ухода, воспитания } \\
\text { и взаимодействия с ним, о себе } \\
\text { как будущем родителе } \\
\text { Представления об отношениях } \\
\text { в семье, планы относительно } \\
\text { родительства }\end{array}$ & $\begin{array}{l}\text { «Ребенок-это...»: } \\
\text { Образ ребенка, себя как бу- } \\
\text { дущего родителя, наполнен- } \\
\text { ность речи разнообразными } \\
\text { категориями }\end{array}$ \\
\hline Поведенческий & $\begin{array}{l}\text { Умения и навыки по уходу, воспи- } \\
\text { танию и общению с ребенком }\end{array}$ & $\begin{array}{l}\text { Игра «День ребенка»: } \\
\text { Характер и разнообра- } \\
\text { зие воспитательных } \\
\text { воздействий. } \\
\text { Навыки по воспитанию } \\
\text { и обучению. } \\
\text { Стиль эмоционального } \\
\text { сопровождения }\end{array}$ \\
\hline
\end{tabular}




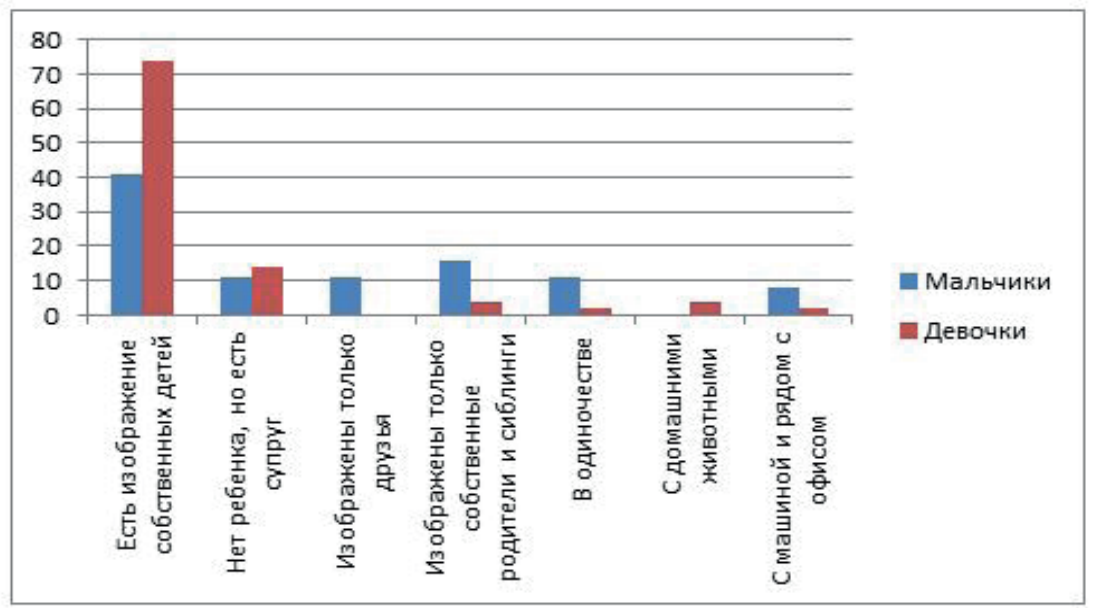

Рисунок 1. Количество младших школьников, изображавших собственных детей на рисунке «Моя семья в будущем» (в \%)

Ценность ребенка на рисунке будущей семьи на высоком уровне лишь у $37 \%$ детей (54\% девочек и $19 \%$ мальчиков). Встречаются высказывания (у $8 \%$ испытуемых), отражающие недифференцированность ценности «ребенка для себя» и ценности «себя как ребенка». Дети отвечали о себе, как о ребенке, а не о других детях («должен учиться на 4 и 5, помогать по дому, пылесосить, мыть посуду, чтобы он ходил в школу, хорошо себя вел, в 10 лет еще ребенок»).

Таким образом, можно предположить, что в младшем школьном возрасте формируется ценность ребенка как таковая, по отношению к детям вообще, однако представления о собственной будущей семье, в которой должны быть дети, еще не сформированы.

Эмоциональный компонент. По результатам контент-анализа данных методики «Рассказ о ребенке» мы можем сделать вывод о преобладании положительного образа ребенка в сознании младших школьников. Среди высказываний у 42 \% испытуемых распространена категория «характер отношения к ребенку» («радость, счастье, сокровище, чудо для взрослых»). Младшие школьники называют детей «веселыми, смешными, забавными». Эти данные представлены на рисунке 2.

Выявились различия в высказываниях детей, имеющих и не имеющих младших сиблингов. Дети, которые высказывались негативно о ребенке, не имеют младших сиблингов, у этих детей выявлен низкий уровень по критерию психологического комфорта в позиции родителя по рисунку «Моя 
семья в будущем», также ценность ребенка у них не сформирована. Дети, у которых есть младшие сиблинги, чаще высказываются положительно или их высказывания носят нейтральный характер.

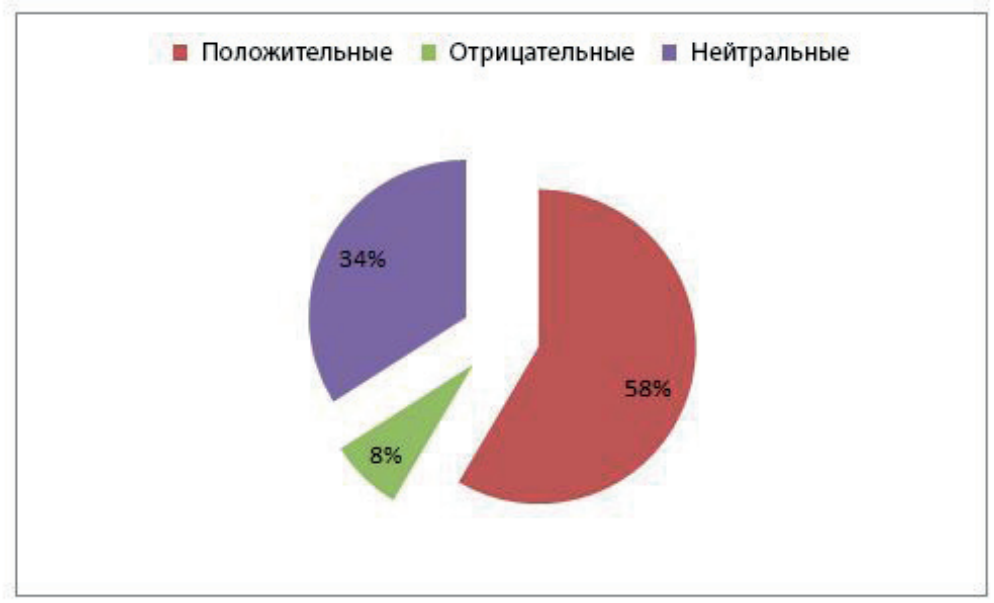

Рисунок 2. Характер высказываний по методике «Рассказ о ребенке»

Преобладает принимающая позиция по отношению к ребенку в режиссерской игре у $87 \%$ испытуемых. Однако психологический комфорт в позиции родителя на рисунке «Моя семья в будущем» наблюдается всего у $19 \%$ детей. Это также подтверждает высказанное выше предположение о том, что в сознании младших школьников еще не полностью дифференцированы ценность себя как ребенка и ценность ребенка для себя.

Когнитивный компонент оценивался по методике «Рассказ о ребенке». Содержание высказываний было проанализировано с помощью контентанализа. Все высказывания были разделены на две категории: 1) образ себя как будущего родителя (характер отношения к ребенку, особенности ухода, воспитания); 2) образ ребенка (внешние качества, особенности поведения, умения, навыки, возраст). Полученные данные представлены на рисунке 3.

Среди высказываний на первом месте категория «маленький человек» у 51 \% детей, на втором месте-«характер отношения к ребенку» (радость, счастье, сокровище, чудо для взрослых) у $42 \%$ детей, на третьем месте внешние качества ребенка (маленький, красивый, есть руки, ноги и др.) у $23 \%$ детей, а также категория «уход и воспитание» (его надо кормить, о нем нужно заботиться, учить читать, рисовать, смотреть, чтобы он не получил травму) у $19 \%$ детей. 


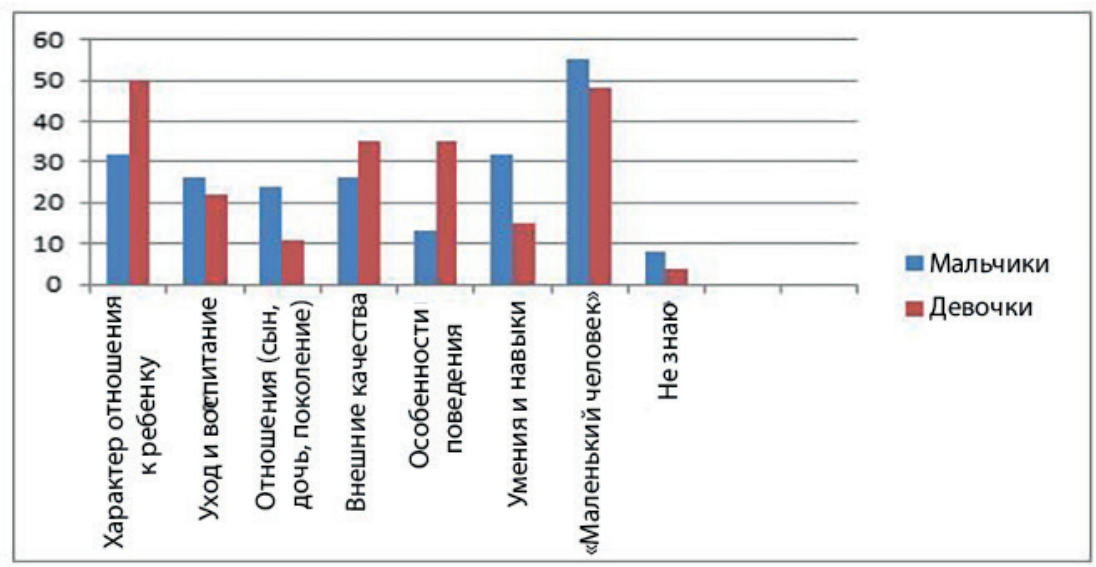

Рисунок 3. Частота использования категорий высказываний младших школьников по методике «Рассказ о ребенке» (в \%)

Наполненность речи разнообразными высказываниями находится на низком уровне почти у половины детей (47\%), у $40 \%$ - средний уровень, а высокий уровень наблюдался лишь у $13 \%$ испытуемых (от 6 до 9 высказываний). Это указывает на то, что когнитивный компонент ВПР в младшем школьном возрасте у $47 \%$ детей еще недостаточно сформирован и характеризуется формальностью представлений.

Поведенческий компонент оценивался по режиссерской игре «День ребенка». Стиль эмоционального сопровождения родителя (компенсация, усиление, игнорирование, осуждение) [16] практически не отличается у мальчиков и девочек. Компенсация как реакция на отрицательное состояние ребенка используется практически всеми детьми (96\%) в большинстве ситуаций. Однако мальчики немного чаще используют другие стили, такие как усиление, игнорирование и осуждение. Эти данные представлены в таблице 2.

Таблица 2.

Стиль эмоционального сопровождения родителя (в \%)

\begin{tabular}{|c|c|c|c|}
\hline $\begin{array}{c}\text { Стиль эмочио- } \\
\text { нального сопрово- } \\
\text { ждения родителя }\end{array}$ & Девочки & Мальчики & Все \\
\hline Компенсация & 96 & 96 & 96 \\
\hline Усиление & 13 & 27 & 20 \\
\hline Игнорирование & 20 & 27 & 23 \\
\hline Осуждение & 16 & 27 & 21 \\
\hline
\end{tabular}


Среди воспитательных воздействий у всех детей на первом месте руководство (79\%) и поддержка (81\%). Девочки немного чаще мальчиков используют успокаивание в ситуациях отрицательных эмоций ребенка, мальчики - поощрение, наказание и принуждение, однако эти различия не являются статистически значимыми. Результаты представлены в таблице 3.

Таблица 3.

Воспитательные воздействия (в \%)

\begin{tabular}{|c|c|c|c|}
\hline $\begin{array}{c}\text { Воспитательные } \\
\text { воздействия }\end{array}$ & Девочки & Мальчики & Все \\
\hline Руководство & 87 & 69 & 79 \\
\hline Поддержка & 83 & 77 & 81 \\
\hline Успокаивание & 70 & 57 & 20 \\
\hline Поощрение & 13 & 27 & 5 \\
\hline Наказание & 0 & 11 & 3 \\
\hline Принуждение & 0 & 7 & 64 \\
\hline
\end{tabular}

У большинства младших школьников преобладает родительская направленность «на ребенка» $(91,5 \%)$, а не «на себя» $(8,5 \%)$. Родительская включенность (оценивалась как посвящение времени ребенку) распределяется следующим образом: целиком готовы посвятить время ребенку 17,5\% испытуемых, частично-76\%, минимум времени-6,5\% испытуемых.

С целью изучения особенностей уровня развития компонентов ВПР у детей, имеющих младших сиблингов (группа 1) и не имеющих таковых (группа 2), был использован непараметрический критерий Манна -Уитни (SPSS20). Было выявлено, что в первой группе выше уровень развития когнитивных представлений о ребенке (уровень значимости $p=0,033$ ). Также лишь во второй группе встречались дети (9\% от общего числа испытуемых), которые в большей степени говорили о себе, как о ребенке, а не о других детях в рассказе «Что такое ребенок».

С целью изучения факторов, взаимосвязанных с высоким уровнем развития компонентов ВПР, был проведен корреляционный и факторный анализ (SPSS20). На основе проведенного анализа мы выделили наиболее значимые связанные друг с другом показатели развития компонентов ВПР. Результаты факторного анализа представлены в таблице 4. 
Таблица 4.

Результаты факторного анализа (матрица повернутых компонент)

\begin{tabular}{|c|c|c|c|}
\hline \multirow{2}{*}{ Показатели } & \multicolumn{3}{|c|}{ Компоненты } \\
\hline & 1 & 2 & 3 \\
\hline Осуждение & 851 & & \\
\hline Усиление & ,848 & & \\
\hline Принуждение & ,550 & & \\
\hline Негативные слова & 480 & & \\
\hline Враждебность & 460 & & \\
\hline Эмоциональный комфорт мамы & & 614 & \\
\hline Эмоциональный комфорт папы & &, 522 & \\
\hline Положительные высказывания & &, 423 & \\
\hline Высказывания «я как родитель» & & & ,870 \\
\hline Количество детей & & & 840 \\
\hline Формальные высказывания & & &,- 789 \\
\hline Ценность ребенка в игре & & & ,582 \\
\hline
\end{tabular}

На основании полученных данных видно, что высокий уровень развития эмоционального компонента (положительные высказывания о ребенке и характер отношения к ребенку) связан с эмоциональным комфортом мамы и папы на рисунке семьи. Высокий уровень развития когнитивного компонента (наличие высказываний из категории «я как родитель», отсутствие формальных высказываний о ребенке) взаимосвязан с высокой ценностью ребенка в режиссерской игре, а также с желанием иметь большее количество детей в будущем. Желание иметь большое количество детей в будущем (два и более) явилось самым ярким показателем развития мотивационного компонента ВПР у младших школьников. Также мы увидели, что высокий уровень враждебности в семейной ситуации на рисунке семьи связан с использованием негативных слов, принуждения, осуждения, а также усиления как реакции на отрицательное состояние ребенка в режиссерской игре. Таким образом, дети в воображаемой роли родителя по отношению к ребенку воспроизводят опыт детско-родительских отношений, полученный в семье. 


\section{Выводы}

Проведенное эмпирическое исследование позволяет сделать выводы:

1. Содержание компонентов ВПР у детей младшего школьного возраста проявляется в процессе рисования будущей семьи, рассказа о ребенке и режиссерской игры, в которой они принимают на себя воображаемую роль родителя.

2. Высокий уровень сформированности компонентов ВПР у младших школьников наиболее ярко проявляется в желании иметь много детей в будущем, наличии положительных высказываний о ребенке, использовании поддержки в игре по отношению к ребенку в эмоционально значимых ситуациях, высоком уровне ценности ребенка в игре, использовании ласкового обращения к ребенку.

3. Наименее сформированные компоненты ВПР у младших школьниковэто мотивационный и когнитивный. Почти половина детей не изображают собственных детей на рисунке своей семьи в будущем, а их высказывания в рассказе о ребенке носят формальный характер. Эмоциональный компонент характеризуется преобладанием положительного отношения к детям у большинства младших школьников, а также наличием принимающей позиции, поведенческий-преобладанием направленности на ребенка при взаимодействии, использованием поддержки, руководства и компенсации в эмоционально значимых ситуациях.

4. Различия в уровне развития компонентов внутренней позиции ВПР мальчиков и девочек заключаются в следующем: количество девочек с высоким уровнем развития эмоционального компонента ВПР больше, чем мальчиков. Однако содержание когнитивного и поведенческого компонентов ВПР у мальчиков и девочек не отличается, они используют одинаковые категории высказываний о ребенке и одинаковые воспитательные воздействия в игре.

5. Наличие опыта взаимодействия с младенцами (младшими сиблингами) способствует сформированности когнитивного компонента ВПР, а также формированию ценности ребенка и положительного эмоционального отношения к детям.

В заключение отметим, что наше исследование позволило выявить недостаточный уровень сформированности компонентов ВПР у значительной части детей, что указывает на необходимость организации просветительской работы с родителями детей, как на уровне отдельных семей, так и на уровне учреждений образования.

\section{Литература}

1. Божович Л. И. Личность и ее формирование в детском возрасте. - СПб.: Питер, 2008. 
2. Захарова Е.И. Психология освоения родительства: научная моногр. М.: Изд-во ИИУ МГОУ, 2014.

3. Захарова Е. И. Ценность материнства у современных женщин и практика осуществления родительской деятельности // Современная российская семья: психологические проблемы и пути их решения: монография. Астрахань: Изд-во Астраханского государственного университета, Издательский дом «Астраханский университет», 2013. -С. 73-86.

4. Карабанова О. А. Психология семейных отношений и основы семейного консультирования. - М.: ГАРДАРИКИ, 2005. - 320 с.

5. Колесова А. О. Представления младших школьников о родительских ролях: дисс. ... канд. психол. наук. -СПб., 2011.

6. Кон И. С. Ребенок и общество. -М., 1988. - 270 с.

7. Лубовский Д. В. Динамика развития и феноменология внутренней позиции у современных младших школьников // Психологическая наука и образование psyedu.ru. - 2014. - № 1. - URL: http://psyedu.ru/ journal/2014/2/Lubovskiy.phtm

8. Мещерякова С. Ю. Путь к материнству начинается с младенчества // Дошкольное воспитание. - 2002. - № 11. - С. 81-89.

9. Нежнова Т. А. Динамика внутренней позиции при переходе от дошкольного к младшему школьному возрасту // Вестник МГУ. Серия 14. Психология. - 1998. - № 1. -С. 50-61.

10. Николаева В. В., Арина Г. А., Айвазян Е. Б. Структура и содержание внутренней материнской позиции у беременных женщин // Медико-психологические аспекты современной пренатальной и перинатальной психологии, психотерапии и перинатологии. - М., 2005. - С. 40-43.

11. Пальчева Т. В. Психологические условия становления и развития репродуктивных установок в детско-юношеском возрасте: дисс. ... канд. психол. наук. - М., 2006.

12. Поливанова К. Н. Современное родительство как предмет исследования // Психологическая наука и образование psyedu.ru. - 2015. - T. 7. № 3. - C. 1-11. - URL: http://dx.doi.org/10.17759/psyedu.2015070301. doi:10.17759/psyedu.2015070301

13. Попова А. А. Контент-анализ ассоциативного ряда к слову «ребенок» // Перинатальная психология и психология репродуктивной сферы. - 2011. № 1-2. - C. 118-131. - URL: www.perinataljourn.ru

14. Психология родительства. Подходы, проблемы, методы исследования / Под ред. Е. В. Куфтяк. - Кострома: Изд-во ГОУВПО КГУ им. Н. А. Некрасова, 2006. - 144 c.

15. Психология семьи: учебник для студ. учреждений высш. проф. образования / [Н. В. Гребенникова, Е.В.Гурова, Е. И. Захарова, Е. Г. Суркова, 
Г. Г. Филиппова, Н. И. Федотова]. Под ред. Е. Г. Сурковой. - М.: Издательский центр «Академия», 2014. - 240 с.

16. Пухова Т. В. Шесть кукол. Психологический анализ режиссерской игры в «семью» у дошкольников. - М.; Обнинск: Принтер, 2000. - 180 с.

17. Трифонова E. В. Режиссерская игра с опорой на рисунок как метод оценки познавательного развития ребенка дошкольного возраста: дисс. ... канд. психол. наук. - М., 2005.

18. Филиппова Г. Г. Психология материнства: учебное пособие. - М.: Изд-во Института психотерапии, 2002.

19. Филиппова Г. Г. Репродуктивная психология: психологические аспекты репродуктивной функции семьи // Дети и общество: социальная реальность и новации. Сборник докладов на Всероссийской конференции с международным участием «Дети и общество: социальная реальность и новации» / Ред. коллегия: В. А. Мансуров (отв. редактор), А. Ю. Губанова, Ю. В. Ермолаева, Е. Ю. Иванова, Е. А. Колосова, С. Н. Майорова-Щеглова, И. А. Стрельцова, П. С. Юрьев. - М.: РОС, 2014. - С. 975-984.

20. Шаграева О. А. Ориентировочная деятельность в структуре психологической компетентности родителей // Международный журнал прикладных и фундаментальных исследований. - 2010. - № 11. -С. 86-89.

21. Arendell T. Conceiving and investigating motherhood: The decade's scholarship // Journal of Marriage and Family. - 2000. -V. 62. - no. 4. pp. 1192-1207.

22. Elkind D. Ties that Stress: The New Family Imbalance. - Harvard: Harvard University Press, 2009. - 253 p.

\section{References}

1. Bozhovich L. I. Lichnost'i ee formirovanie v detskom vozraste [Personality and its formation in childhood]. St. Petersburg, Piter Publ., 2008.

2. Zakharova E. I.Psikhologiia osvoeniia roditel'stva [The psychology of mastering parenthood]. Moscow, Moscow Region State University Publ., 2014.

3. Zakharova E. I. Tsennost' materinstva u sovremennykh zhenshchin i praktika osushchestvleniia roditel'skoi deiatel'nosti: Sovremennaia rossiiskaia sem'ia: psikhologicheskie problemy i puti ikh resheniia [The value of motherhood in contemporary women and the practice parent activities: Modern Russian family: psychological problems and ways of their solving]. Astrakhan, Astrakhan State University Publ., 2013, pp. 73-86.

4. Karabanova O. A. Psikhologiia semeinykh otnoshenii i osnovy semeinogo konsul'tirovaniia [The psychology of family relations and fundamentals of family counseling]. Moscow, GARDARIKI Publ., 2005. 320 p.

5. Kolesova A. O. Predstavleniia mladshikh shkol'nikov o roditel'skikh roliakh. 
Diss. kand. psikh. nauk [Junior schoolchildren's representations of parental roles. Cand. Psych. sci. diss]. St. Petersburg, 2011.

6. Kon I. S. Rebenok i obshchestvo [A child and society]. Moscow, 1988. 270 p.

7. Lubovskii D.V.The dynamics of development and phenomenology of internal position in contemporary junior schoolchildren. Available at: http://psyedu. ru/journal/2014/2/Lubovskiy.phtm

8. Meshcheriakova S. lu. Put' k materinstvu nachinaetsia s mladenchestva [The road to motherhood starts from childhood]. Doshkol'noe vospitanie Preschool Education, 2002, no. 11, pp. 81-89.

9. Nezhnova T. A. Dinamika vnutrennei pozitsii pri perekhode ot doshkol'nogo $\mathrm{k}$ mladshemu shkol'nomu vozrastu [The dynamics of internal position when passing from preschool to primary school]. VestnikMGU - Bulletin of Moscow State University. Series 14. Psychology, 1998, no. 1, pp. 50-61.

10. Nikolaeva V. V., Arina G. A., Aivazian E. B. Struktura i soderzhanie vnutrennei materinskoi pozitsii u beremennykh zhenshchin: Mediko-psikhologicheskie aspekty sovremennoi prenatal'noi i perinatal'noi psikhologii, psikhoterapii i perinatologii [The structure and content of internal maternal position in pregnant women: Medical and psychological aspects of modern prenatal and perinatal psychology, psychotherapy, and perinatology]. Moscow, 2005, pp. 40-43.

11. Pal'tseva T.V. Psikhologicheskie usloviia stanovleniia i razvitiia reproduktivnykh ustanovokv detsko-iunosheskom vozraste. Diss. kand. psikh. nauk [Psychological conditions of the formation and development of reproductive attitudes in childhood and adolescence. Cand. psych. sci. diss]. Moscow, 2006.

12. Polivanova K. N. Modern parenthood as a subject of research. Available at: http://dx.doi.org/10.17759/psyedu.2015070301. doi:10.17759/psyedu. 2015070301

13. Popova A. A. Kontent-analiz assotsiativnogo riada k slovu «rebenok» [The content analysis of associations to the word "child"]. Perinatal'naia psikhologiia i psikhologiia reproduktivnoi sfery - Perinatal Psychology and Psychology of Reproductive Sphere, 2011, no. 1-2, pp. 118-131.

14. Kuftiak E. V. Psikhologiia roditel'stva. Podkhody, problemy, metody issledovaniia [The psychology of parenthood. Approaches, problems, and methods of research]. Kostroma, Kostroma State University Publ., 2006. 144 p.

15. Surkova E. G. Psikhologiia sem'i [Family psychology]. Moscow, Akademiia Publ., 2014. 240 p.

16. Pukhova T. V. Shest' kukol. Psikhologicheskii analiz rezhisserskoi igry v «sem'iu» u doshkol'nikov [Six dolls. Psychological analysis of the family game of preschoolers]. Moscow; Obninsk, Printer Publ., 2000. 180 p.

17. Trifonova E. V. Rezhisserskaia igra s oporoi na risunok kak metod otsenki 
РОССИЙСКИЙ ПСИХОЛОГИЧЕСКИЙ ЖУРНАЛ • 2016 ТОМ 13 № 3

poznavatel'nogo razvitiia rebenka doshkol'nogo vozrasta. Diss. kand. psikh. nauk [Video games based on drawing as a method of evaluating cognitive development of children of preschool age. Cand. psych. sci. diss]. Moscow, 2005.

18. Filippova G. G. Psikhologiia materinstva [The psychology of motherhood]. Mosocw, Institute of Psychotherapy Publ., 2002.

19. Filippova G. G. Reproduktivnaia psikhologiia: psikhologicheskie aspekty reproduktivnoi funktsii sem'i [Reproductive psychology: psychological aspects of the reproductive function of the family]. Sbornik dokladov na Vserossiiskoii konferentsii s mezhdunarodnym uchastiem "Deti i obshchestvo: sotsial'naia real'nost' i novatsii" [Proc. the All-Russian Conference with International Participation "Children and society: social reality and innovations"]. Moscow, 2014, pp. 975-984.

20. Shagraeva O. A. Orientirovochnaia deiatel'nost' v strukture psikhologicheskoi kompetentnosti roditelei [Orientation activities in the structure of psychological competence of parents]. Mezhdunarodnyi zhurnal prikladnykh i fundamental'nykh issledovanii - International Journal of Applied and Fundamental Research, 2010, no. 11, pp. 86-89.

21. Arendell T. Conceiving and investigating motherhood: The decade's scholarship. Journal of Marriage and Family, 2000, V. 62, no. 4, pp. 1192-1207.

22. Elkind D. Ties that Stress: The New Family Imbalance. Harvard: Harvard University Press, 2009. 253 p. 